\title{
A study on the impact of strategic HR practices and organizational learning on perceived organizational performance in Sharjah public sectors
}

\author{
Amna Salim Alsuwaidi \\ University of Dubai \\ s20141008@ud.ac.ae \\ $\&$ \\ Arunprasad \\ University of Dubai \\ arun@ud.ac.ae
}

\begin{abstract}
:
This paper attempts to present a conceptual framework to understand the importance and impact of strategic HRM practices and organizational learning capability on the overall performance of the organization. At the same time, the role of learning outcomes is also examined in this relationship as an intervening variable. As per the previous research conducted in the area of strategic HRM and organizational performance, it is observed that strategic HRM have a positive impact on the overall performance of the public sector. Alongside, the organizational learning capability and the prevailing learning culture enhances the performance of the organization in terms of innovation and tangible learning outcomes Moreover, strategic HR practices are one of the most important factors to enhance the employee's skills and maintain them as per the individuals and organizations developmental need in public sector. Thus, the conceptual framework in this study encompasses strategic HRM practices, organizational learning capability and learning culture as independent variables, organizational performance as dependent variable with learning outcomes as an intervening variable.
\end{abstract}

Keywords: strategic HR practices, organizational learning, learning outcome, innovativeness

http://dx.doi.org/10.30585/icabml-cp.v1i1.25

2523-6547 - Copyright: ( 2017 The Authors. This is an open access article distributed under the terms of the Creative Commons Attribution License, which permits unrestricted use, distribution, and reproduction in any medium, provided the original author and source are credited. 
2523-6547 - Copyright: (C) 2017 The Authors. This is an open access article distributed under the terms of the Creative Commons Attribution License, which permits unrestricted use, distribution, and reproduction in any medium, provided the original author and source are credited. 


\section{INTRODUCTION:}

\subsection{Overview of Sharjah public sectors}

There are more than (50) public sectors in Sharjah that can be differentiated based on different categories such as company size, service types, financial and so on. The public sectors are founded to provide services and/or products needed to its community; also, one of its duties is to conduct the needed studies and plans that could raise the resources and enhance the performance of each organization; as a result, government's income will be enhanced. Moreover, the public sectors are established based on the decisions and legislation issued by His Highness Sheikh Dr. Sultan Bin Mohammed Bin Sultan Al Qassimi, Member of the UAE Supreme Council and Ruler of Sharjah. Although, all the public sectors are having diverse responsibilities and goals to be accomplished, they have common strategic goals such as encourage the employees to adopt best practices that can be used to enhance and gain the community satisfaction and customer loyalty, and to ensure the continuous of the human and technical resources developments.

According to Sharjah Investment \& Development Authority's newsletter, government of Sharjah plays a significant role in providing jobs on public sectors to reduce the rate of unemployment in order to raise Emiratization and to enhance its employees' living standards (Sharjah update newsletter, 2015). Currently, the growth rate of sharjah city has been increasing; as a result, both of economic diversification and organizational innovation have been developed and enhanced.

Besides that all, the government of Sharjah supports talented employees and encourage innovation by allocating an annual budget that use for employees development plan, training programs, scholarship programs in order to encourage the continuous learning. To illustrates; the Directorate of Human Resources in Sharjah provides an annual training guide for all employees who are working in public sector with all levels in order to enhance their professionalism. Moreover, the government of Sharjah supports His Highness Sheikh Mohammed bin Rashid Al Maktoum, Vice President and Prime Minister of the UAE and Ruler of Dubai's innovation vision by adopting a development plan that contains on an innovative training programs in order to enhance both of the employees' professions and innovative abilities.

\subsection{Major management Challenges in Public Sectors in Sharjah}

There are several management challenges found in public sectors. (Cerimagic, 2010) (AlMazrouei \& Pech, 2015) have found that expatriate managers face cultural issues in public sector. Moreover, organizations should not rely on woman empowers, contribution to society, or capabilities only but also on encouraging cultural diversity within the organization (Cornwell, 2013). Furthermore, managers should consider cultural differences in the organization since it leads to enhance the development of the organization by having diverse and fresh ideas (Smith, 2013). However, since the Middle East contains on people from different nationalities, cultural difference can cause a problem if it was not managed probably. On the other hand, differences in both cultures and employees ages are considered as important key factors for group thinking. For instance, old employees have better experience and knowledge that they can share with others.

Another challenge is learning and career development; employees are looking for career development plan that ensures their future development in the organization more than compensation (Cornwell, 2013). There are more than $(60 \%)$ of employees believe that their organizations do not provide the essential learning tools or programs to meet talent-related challenge (AG-reporter, 2015). Moreover, HE Abdul Rahman S. Al-Otaishan is

2523-6547 - Copyright: (C) 2017 The Authors. This is an open access article distributed under the terms of the Creative Commons Attribution License, which permits unrestricted use, distribution, and reproduction in any medium, provided the original author and source are credited. 
the Chairman of Asharqia Chamber encourages organizations to provide employees' development programs that raise their capabilities and to fill job in order to maintain the talented employees (al khaleej-newspaper, 2017).

\subsection{The purpose and the Need for the current Study}

The purpose of this study is to identify and test the strategic HR practices and organizational learning on learning outcomes and organizational performance.

Hence, the need for the study is to address one of the management challenges to harness the human capital and develop the potential resources through continuous learning and providing an environment of the knowledge sharing in Sharjah public sectors

\section{LITERATURE REVIEW}

\subsection{Strategic HRM Practices and Organizational Performance}

Human capital is well known for its effectiveness on organization learning but if the organizations don't use them in a right way; it will not achieve the results needed. According to (Barney J., 1991), (Ambrosini, 2000), (Kang, Morris, \& Snell, 2007), organizations can't gain a competitive advantage without using its ability to create and develop new knowledge within the organization, although that human capital plays an important role on the organization. Moreover, (Rutherford, Buller, \& McMullen, 2004) have added that most organizations have become more aware of the importance of HRM to ensure organizations' success. Also, (Chew \& Sharma, 2005) has addressed that currently HR has been widely increased because of it plays a significant role in the organizations; for example, top HR executives can participate in decision-making that enhance the output of the organizations. In addition to that, (Paauwe J. a., 2005) have mentioned that organizations can have impact on employee's behavior in order to achieve the desired direction of the organization strategy by implanting HR practices.

Moreover, organizations should consider the importance of enhancing its learning strategy within a planned time frame. As (Crossan, Lane, \& White, 1999) mentioned that organization should manage its learning strategy for both of short and long term in order to meet its customers demand and develop its assets. Also, (Juani S. \& Nicholas K., 2010) supports (Crossan, Lane, \& White, 1999) concept by adding that managing human resources within accelerated time frame will give a different results from managing the human resources on planned time frame. Furthermore, (Boxall \& Purcell, 2000)mentioned that HR practices could assist on motivating and developing employees skills and knowledge. As (Becker \& Gerhart, 1996)stated, human resource management (HRM) practices play a crucial role in creating and sustaining organizational performance. Moreover, HRM practices can enhance the employees' skills, abilities, values, belief, attitudes and behaviors (Fong, Ooi, Tan, Lee, \& Chong, 2011)

In addition to that, knowledge sharing plays an important role in improving organization's value and mission because it assists on increasing employees' experience. Knowledge sharing is about exchanging the information, and knowledge through the organization (Yang, 2007) to encourage the employees to refinement of old knowledge and generate new ones that could improve organization's process and services and to create a sustainable competitive advantage (Lin, 2007). According to (Fong, Ooi, Tan, Lee, \& Chong, 2011), knowledge might show slight results in case if it is not widely shared among the employees within the organization; as a result, it causes employees to find better opportunities in other organization. (Koskinena, Pihlantob, \& Vanharantaa, 2003)

2523-6547 - Copyright: (C) 2017 The Authors. This is an open access article distributed under the terms of the Creative Commons Attribution License, which permits unrestricted use, distribution, and reproduction in any medium, provided the original author and source are credited. 
Defined two types of knowledge's: explicit knowledge that shares the information among the employees and tacit knowledge that is difficult to share among the employees such as belief and experience.

According to (Huselid M. , 1995) (Huselid, Jackson, \& Schuler, 1997) using best human resource practices can enhance organization performance because those practices can motivate and enhance employees ability, while, (Barney \& Wright, 1998) argue that in some situations the implementation of human resources practices can be failed if they do not reinforced with some variables. So, HR practices should be matched with organization's strategic requirements in order to have a positive impact of HRM on organization performance (Youndt, Snell, Dean, \& Lepak, 1996). According to (Shih, Chiang, \& Hsu, 2006) stated that adopting HR practices can enhance organizational decisions and performances while (Hooi \& Ngui, 2014) have stated that organizations should adopting the right HR practices' set in order to ensure having an enhanced organizational outcomes. (Wright \& McMahon, 1992) (Delery \& Doty, 1996) have supported that adopting the right set of HR practices is important to have a better organizational performance. (Farouk, Elanain, Obeidat, \& Al-Nahyan, 2016) have mentioned that HR practices plays a significant role in leading to organizations success by having an impact on human capital.

Moreover, (Hooi \& Ngui, 2014) gave interesting insight on importance of HRM in creating new opportunities for employees and encouraging them to be innovative. Besides that all, (Hooi \& Ngui, 2014) have noted that human capital is an important elements to ensure gaining competitive advantage since it has a direct impact on the organizations. Also, HRM systems have shown its benefits on enhancing HR practices (Delery \& Shaw, 2001).

The most important thing is to design the HRM system to fit both of organizations" characteristics and environment in order to achieve the desire outcome (Lengnick-Hall, Lengnick-Hall, \& Rigsbee, 2013).

Moving on, (Marquardt, 1996) has identified organization learning outcomes' dimensions as learning dynamics, organization transformation, people empowerment, knowledge management, and technology application. These dimensions are used as measureable intervening variables for learning outcomes.

\subsection{Organizational Learning Capability (OLC), Learning Culture (LC) and Learning Outcomes}

\section{ORGANIZATIONAL LEARNING CAPABILITY}

(Wei, Wu, Cheung, \& Chiu, Winter 2011/2012) say that organization capability shows the ability of the organization in performing its basics operation. Actually, organizational capability can lead to gain sustainable development and to enhance organization's performance. (Bharadwaj, 2000) (Kogut \& Zander, 1992) (Zott, 2003). Thus, organizations need to identify its capability in order to cope with external environment's challenges and to sustain a competitive advantage (Teece, Pisano, \& Shuen, 1997) (Wei, Wu, Cheung, \& Chiu, Winter 2011/2012). (Hooi \& Ngui, 2014)confirmed that several researcher's emphasis on the importance of developing organizational learning capability to accomplish desire goals and to meet competitive strategies' requirements; also, they added that researchers identify organization learning as a process of developing organization's knowledge. Furthermore, (Crossan, Lane, \& White, 1999) defined organization learning as a social structure that contains on actions and interactions of individual, group, and organization. Also, (Amit \& Schoemaker, 1993) defined organization-learning capability as an organization ability to use its internal resources to achieve a desire goal. (Jerez-Gomez, Cespedes-Lorente, \& Valle-Cabrera, 2005) have defined organizational learning capability as a knowledge process that works on creating and transferring ideas and concepts among employees in order to enhance organization performance. Also, (Chiva, Alegre, \& Lapiedra, 2007) (Chiva \& Alegre, 2009)have defined organizational learning capability as factor that encourages learning process within the organization. (Limpibunterng \& Johri, 2009) have pointed out that organizational learning capability allows the organizations to create and to enrich their knowledge that lead to competiveness toward enhancing organizational performance;

2523-6547 - Copyright: (C) 2017 The Authors. This is an open access article distributed under the terms of the Creative Commons Attribution License, which permits unrestricted use, distribution, and reproduction in any medium, provided the original author and source are credited. 
also they have added that based on several studies, there is a significant impact of organizational learning capability on organizational performance.

Moreover, (Goh, Elliott, \& Quon, 2012) have added that developing organization-learning capability to achieve a desire goal can enhance organization performance and encourage knowledge developments. Also, (Hooi \& Ngui, 2014) have pointed out that there are several studies highlighted that a strong learning capability will assist the development of the organizations in term of enhancing both of competitive strategies and effective learning.

(Hedberg, 1981) (Murray \& Donegan, 2003) have noted that organization learning is not only concerned with what an individual has learned but also it about enhancing organization's actions because of its individual's improved capability and behavior. Also, (Stata, 1989)\& (Kim, 1998) supports that organization learning can encourage knowledge sharing based on organization's experience as a result, it will assist the organization to plan for an effective action and to enhance its capability.

In addition, even if the organizations are using an advanced technology or techniques they may not be able to innovate if they do not have talented employees for that; thus, organizational learning practices and capabilities are essential for innovation (Wang \& Ellinger, 2011) (García-Moralesa, Lloréns-Montesa, \& VerdúJoverb, 2007) (López, Peón, \& Ordás, 2005).

Moving on, (Jerez-Gomez, Cespedes-Lorente, \& Valle-Cabrera, 2005) have identified four dimensions of organizational learning capability; managerial commitment, shared perspective, open-mindedness and knowledge integration. The four dimensions will be used in the model of this study.

\section{Learning culture}

With the organizational learning, organizations can encourage the employees to interpret their gained experience based on cultural orientation. (Schein, 1997) has defined organizational culture as assumptions, beliefs and core values patterns that can be used for both of interpretation and problem solving. Also, (Breda-Verduijn \& Heijboer, Learning culture, continuous learning, organizational learning anthropologist, 2016) have defined organizational cultural as assumptions, values, and norms that have been gained during learning process in the organization. Moreover, organizations that believe on learning culture will have an inimitable identity that assist on performing all the activities within the organization. (Gagliardi, 1986) (Schein, 1997). (Jandeska \& Kraimer, 2005) (Sengupta \& Sinha, 2005) (Nawab, Shafi, \& Ahmad, 2010) support that organizational culture has an impact on both of employee's commitment and defining their identity within the organization. Also, several studies discussed the importance of organizational learning in term of enhancing employees' attitudes and organization outcomes (Ellinger, Ellinger, Yang, \& Howton, 2002) (Egan, Yang, \& Bartlett, 2004) (Kontoghiorghes, Awbre, \& Feurig, 2005), although the positive result of organizational learning cultural takes time to be measured (Sorakraikitikul \& Siengthai, 2014). In addition to that, several studies discussed the importance of organizational cultural in term of gaining competitive advantages (Moorsel, 2003) (Takeuchi \& Nonaka, 1995) (Watkins \& Marsick, 1996) (Yolles, 2009) (Breda-Verduijn \& Heijboer, Learning culture, continuous learning, organizational learning anthropologist, 2016). However there are several studies discussed the impacts of the organizational learning culture on employees' knowledge sharing, commitment and satisfaction; there are several organizations still not aware about the importance and impacts of culture on employees. (Egan, Yang, \& Bartlett, 2004) (Wang X. , 2007) (Sorakraikitikul \& Siengthai, 2014). On the other hand, cultural diversity especially in large-size organizations, it might become complicated because employees with similar cultural background will form various subculture groups within the organizations (Vijayakumar \& Padma, 2014).

Learning culture levels has been categorized as: reflexive, bounded, and critical (Tran, 2008). A reflexive level is a basic learning behavior level that shows a reaction to stimuli at no level of causal relationship

2523-6547 - Copyright: (C) 2017 The Authors. This is an open access article distributed under the terms of the Creative Commons Attribution License, which permits unrestricted use, distribution, and reproduction in any medium, provided the original author and source are credited. 
understanding (Salancik \& Meindl, 1984); (Starbuck, 1983). (Tran, 2008)Mentioned that people on this level do not show their eager to understand a cause-effect relationship that lead to enhance the organization's performance due to limited ability, resources and low incentives that can be used to enhance their performance, so at this level organization should develop an advance learning culture in order to maintaining its existing capabilities and encourage innovation. Also, (Tran, 2008) has added that organizations at this level start to create new innovative products only when they are unable to survive in the market due to competitor's activities.

Another learning culture level is called a bounded level that encourages organizations to gain an understanding of a direct cause and effect relationship based on their environment assumptions to enhance current infrastructure (Slater \& Narver, 1995). (Tran, 2008) Stated that although at this level employee's activities is governed and followed by organizations' rules and policies, they can enhance their knowledge and capabilities to have a creative ideas that encourage innovation and enhance organization's performance by understanding customer's needs. Finally, the third level of learning is culture that called a critical learning. A critical learning allows organizations to identify the needed enhancements in order to make necessary changes. (Ronald E Purser, 1992) Notes that organizations investigate its structure to know what should be changed or eliminated in order to meet its new goal.

(Garvin D. , 1985) has mentioned that organizational learning culture assists organizations to be skilled in gaining and exchanging information that allows to adapt new knowledge and insights.

\subsection{OLC, LC and Innovation}

some of the organizations have been failed to implement innovations process on their workplace the reasons behind that are because of inadequate skills, knowledge and resources. (Amabile, 1988) (Dougherty, 1996). Thus, (Tran, 2008) has recommended that organizations should encourage employees' engagement, change the structure of the organizations, and adopt performance measurements tools in order to enhance both of creativity and collaboration in work environment. Moreover, (Ahmed, 1998)has mentioned that some organizations fail to implement innovation although that innovation becomes an important factor of organizations succeed in the market. (Grant R. , 1996) has mentioned that innovation enables organizations to adjust their capabilities based on current or needed changes; moreover, the (Grant R., 1996) has added that knowledge is an important resource for innovative capability.

According to (Zltman, Duncan \& Holbek, 1973), in initiation stage of innovation shows the willing of the organization's members to adopt the innovation. Thus, as Van de Ven (1986) mentioned organizations should recognize their needs to create new ideas. Moreover, (Sluis, 2004) mentioned that to organizations should encourage work environment that support learning and innovation. (Ekvall \& Ryhammar, 1999)Support that organization's work environment has a significant impact on both of learning and innovation. In addition to that, (Damanpour, 1991) has mentioned that innovation is an essential element to generate new methods, process, products, and services that meet customers' needs.

Moving on to technological \& organizational innovation, (OECD, 1997), an organization for Economic Co-operation and Development, technological innovation is about enhancing or introducing new products or services by implementing the technology in production process; for example, technology transfer that allow technology's knowledge or process to be transferred among the organization (Ismail M. , 2005). While organizational innovation allows employing an advance management's approaches and techniques that allowed providing appropriate information of managerial innovation that assist enhancing organizations' services and products (OECD, 1997). Furthermore, (Kanter, 1984) point out that innovation is not only about technological innovation but also can be used in organizational learning to support innovation.

Nowadays, innovation has become as an important factor for any organization to grow and survive in the market. However, there are several organizations that promote innovation to enhance their strategy; they fail to 
meet expectations. According to (Tran, 2008), the existence of an organizational learning culture encourage innovation succeed in organization. Furthermore, (Breda-Verduijn \& Heijboer, Learning culture, continuous learning, organizational learning anthropologist, 2016) have mentioned that learning culture is an important elements for organizational innovation since it seeks to enhance learning and increase creativity especially on problem solving; thus organizations will determine the needed changes; as well; the organizations ability to learn and engage in culture collaborations assist the them to do better than others in term of innovation. Also, (Hussein, Omar, Noordin, \& Ishak, 2016) has added that organizational learning culture encourages organizational developments and improvements that promote innovation as well (Kieser \& Koch, 2008) have pointed out that organizational learning culture lead to innovation capabilities enhancements. Moreover, (Baldwin \& Ford, 1988) (Bates \& Khasawehn, 2005)supports that organizational cultural can encourage organizational innovation. Organizations can get benefits from supporting learning cultural to inspire creating new knowledge that can be used in innovation (Kontoghiorghes, Awbre, \& Feurig, 2005) (Nonaka, Toyama, \& Hirata, 2008). Also, (BredaVerduijn \& Heijboer, Learning culture, continuous learning, organizational learning anthropologist, 2016) have mentioned that organizations should attract talented people in order to encourage and to enhance organizational innovation by getting benefit from the generation of the millennials.

Moreover, (Bates \& Khasawneh, 2005) have mentioned that organizational learning culture plays an important role on organizational innovation because it enables the organizations to adapt to new changing environment. Also, they have mentioned that organizational learning culture and innovation assist on exchanging the ideas and information in order to encourage learning within the organization. (Breda-Verduijn \& Heijboer, Learning culture, continuous learning, organizational learning anthropologist, 2016) have supported that organizational learning culture support learning exchange and transfer within the organization that lead to have continuous improvements and innovations.

In this study learning culture variables that was defined by (Tran, 2008) such as reflexive learning, bounded learning, critical learning will be used in the model.

2523-6547 - Copyright: (C) 2017 The Authors. This is an open access article distributed under the terms of the Creative Commons Attribution License, which permits unrestricted use, distribution, and reproduction in any medium, provided the original author and source are credited. 


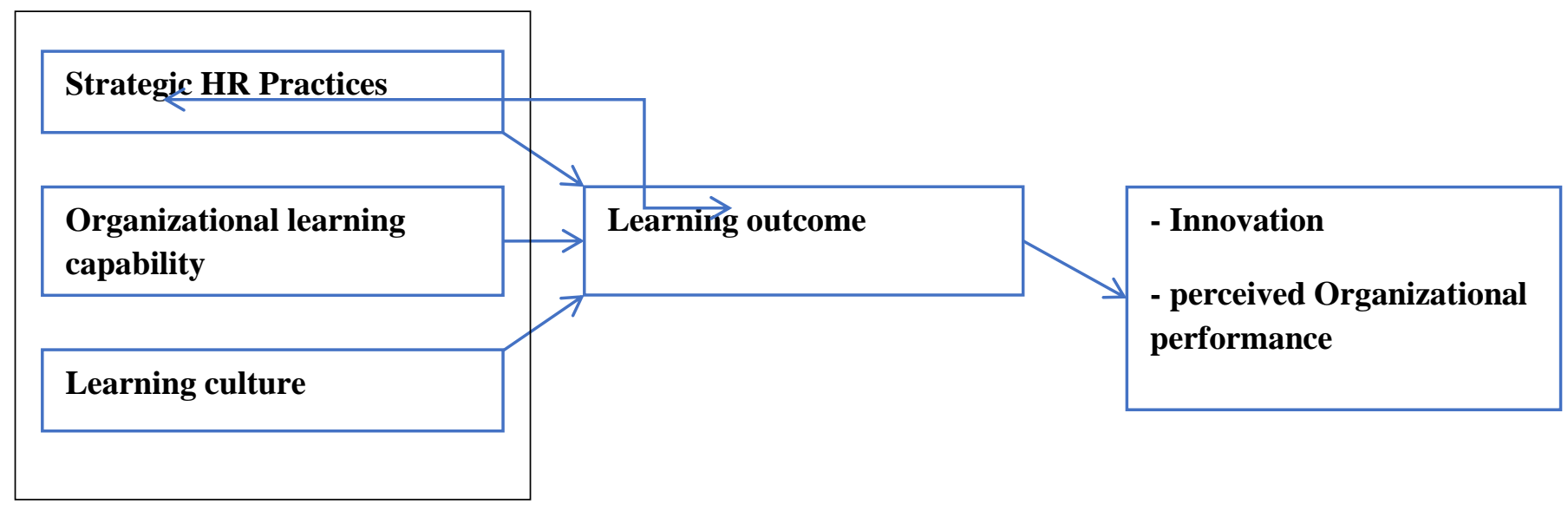

The specific strategic HR practices, learning capabilities and learning culture can reinforce the learning outcome towards adopting innovation, and enhancing performance. Moreover, the learning outcome bridges the gap between HR practices, learning capability, learning culture and both of organization innovation and performance.

(Barney J. , 1986) (Barney J. , 1991) has explained that HR practices are important for the organizations to gain a competitive advantage which lead to performance enhancing. Moreover, (Paauwe \& Boselie, 2005) have stated that using HR practices in motivating the employees will raise organization's performance level because employees will perform the job in a better way. Also, (Hiltrop, 1996) has supported that implementing HR practices will lead to have motivated employees who support organization's strategies. So, it is hypothesized that:

Proposition 1: strategic HR practices are positively related to perceived organizational performance.

HR practices play a vital role in developing organization's innovativeness strategies by encouraging the employees to take responsibilities through out empowerment and participation (Wang Z. M., 2005). (Gupta \& Singhal, 1993)have found that HR practices can assist the employees to introduce range of product innovation. According to (Chen \& Huang, 2009), innovative products require creative employees who introduce new product. Also, based on several studies, we found out that HR practices have a significant role in enhancing organization's innovation. So, it is hypothesized that:

2523-6547 - Copyright: (C) 2017 The Authors. This is an open access article distributed under the terms of the Creative Commons Attribution License, which permits unrestricted use, distribution, and reproduction in any medium, provided the original author and source are credited. 
Proposition 2: strategic HR practices are positively related to innovation.

Organizational learning capabilities play a significant role in encouraging organization's learning process in order to achieve a competitive advantage that ensures enhancing organizational performance (Jiménez-Jiménez \& Sanz-Valle, 2011). (Kalmuk \& Acar, 2015) have supported that organizational learning capabilities lead to gain a sustainable competitive advantage that develop the organizational performance. Moreover, (Fiol \& Lyles, 1985) (Senge P. , 1990) (Slater \& Narver, 1995) have mentioned that the process of organizational learning allows employees to share their experience and knowledge that impact organization's capabilities. So, it is hypothesized that:

Proposition 3: Organizational learning capability is positively related to perceived organizational performance.

(Liao, Fei, \& Liu, 2008)have found that organizational learning capability allows employees to be creative and to introduce new innovative ideas so it is considered as a one of innovative essential. In addition, (Argyris \& Schon, 1978)have mentioned that innovations can be improved by encouraging organizational learning. So, it is hypothesized that:

Proposition 4: organizational learning capability is positively related to innovation

As explained in pervious section, organizational learning culture is important to enhance organizational performance as a result of that organizations can gain a competitive advantage (López, Peón, \& Ordás, 2005). Moreover, (Bontis, Crossan, \& Huallnd, 2002) (Kandekar \& Sharma, 2006) have pointed out that organizational learning culture has an impact on financial performance; as well (Akhtar, Arif, Rubi, \& Naveed, 2011) have pointed that organizational learning culture lead to higher performance of the organization. Moreover, (Hussein, Omar, Noordin, \& Ishak, 2016)have found out that continuous organizational learning culture has a superior influence on individual performance more than organizational performance. So, it is hypothesized that:

Proposition 5: There is a significant effect of organizational learning culture on perceived organizational performance.

Organizational learning culture is an essential element in supporting organizational innovativeness since it is encourage knowledge development among the employees (Hult, Hurley, \& Knight, 2004) (Hurley \& Hult, 1998). Moreover, (Ussahawanitchakit, 2008) has proven that there is a positive influence of organizational learning culture on organizational innovativeness. So, it is hypothesized that:

Proposition 6: There is a significant effect of organizational learning culture on innovation.

Proposition 7: Learning outcome mediates the relationship between HR practices and innovation / perceived organization performance

Proposition 8: Learning outcome mediates the relationship between OLC and innovation / org performance

Proposition 7: Learning outcome mediates the relationship between organizational learning culture and innovation / org performance

2523-6547 - Copyright: (C) 2017 The Authors. This is an open access article distributed under the terms of the Creative Commons Attribution License, which permits unrestricted use, distribution, and reproduction in any medium, provided the original author and source are credited. 


\section{CONCLUSION}

In short, this study aims to provide a comprehensive conceptual framework about HR practices, organization capabilities, and learning culture with innovation and organization performance. We found out that HR practices play a vital role in enhancing the organizational outcome and performance; also, it's significant for organizational development. Furthermore, enhancing employee's skills and learning ability will have a directly impact ton enhancing organizational learning outcome. HR practices can assist the organizations to gain a competitive advantage by developing its strategies and systems (Hooi \& Ngui, 2014).

Moreover, we found out that using organizational capabilities dimensions can assist us to determine their impacts on organizational outcome and performance; as well, to determine the resources that can be used to enrich the organizational learning capability.

For future potential research, we suggest that different variables of organizational capability should be defined to know how each variable could add value to the organization. 


\section{Works Cited}

AG-reporter. (2015, June 16). Top Challenges Faced by HR in the Middle East. Retrieved Aug 11, 2016, from Arabian Gazette: http://www.arabiangazette.com/top-challenges-faced-hr-middle-east-20150616/

Ahmed, P. K. (1998). Culture and climate for innovation. European Journal of Innovation Management , 1 (1), $30-43$.

Akhtar, S., Arif, A., Rubi, E., \& Naveed, S. (2011). Impact of learning on organizational performance: Study of higher education institutes. International Journal of Academic Research , 3 (5), 327-331.

al khaleej-newspaper. (2017, June 01). The Conference on Human Resources in the "Cooperation" countries discusses the challenges. Retrieved from al khaleej-newspaper: http://www.alkhaleej.ae/home/print/a922472b3d18-4d8e-80b8-4c95e68a97f2/ce24353f-ad1d-488e-9d89-5d2e0644501d

Al-Alawi, A. I., Al-Marzooqi, N. Y., \& Mohammed, Y. F. (2007). Organizational culture and knowledge sharing: critical success factors. Journal of Knowledge Management , 11 (2), 22-42.

Aladwan, K., Bhanugopan, R., \& D’Netto, B. (2015). The effects of human resource management practices on employees' organisational commitment. International Journal of Organizational Analysis , 23 (3), 472 - 492.

AlMazrouei, H., \& Pech, R. J. (2015). Working in the UAE: expatriate management experiences. Journal of Islamic Accounting and Business Research , 6 (1), 73-93.

Alnaqbi, W. (2011). The relationship between human resource practices and employee retention in public organisations : an exploratory study conducted in the United Arab Emirates. Retrieved Feb 25, 2017, from Edith Cowan University: http://ro.ecu.edu.au/theses/424

al-Yahya, D. K. (2011, 1 18). Managing human resources remains challenge to growth. Retrieved Aug 7, 2016, from the national: http://www.thenational.ae/business/industry-insights/economics/managing-human-resourcesremains-challenge-to-growth

Amabile, T. M. (1988). A model of creativity and innovation in organizations (Vol. 10). (B. a. in Staw, Ed.) Greenwich, CT: Research in Organizational Behavior.

Ambrosini, C. B. (2000). Value creation VS value capture: towards a coherent definition of value in strategy. British Journal of Management , 11 (1), 1-15.

Amit, R., \& Schoemaker, P. J. (1993). Strategic assets and organizational rent. Strategic Management Journal , $14(1), 33-46$.

Argyris, C., \& Schon, D. A. (1978). Organizational Learning: A Theory of Action Perspective. MA: AddisonWesley Series on Organization Development.

Baldwin, T., \& Ford, J. (1988). Transfer of training: a review and directions for future research. Personnel Psychology, 41, 63-105.

Barnes, J., \& Liao, Y. (2012). The effect of individual, network, and collaborative competencies on the supply chain management system. International Journal of Production Economics , 140 (2), 888-899.

Barney, J. B., \& Wright, P. M. (1998). On becoming a strategic partner: the role of human resources in gaining competitive advantage. Human Resource Management, 37 (1), 31 - 46.

2523-6547 - Copyright: (C) 2017 The Authors. This is an open access article distributed under the terms of the Creative Commons Attribution License, which permits unrestricted use, distribution, and reproduction in any medium, provided the original author and source are credited. 
Barney, J. (1991). Firm resources and sustained competitive advantage. Journal of management, 17 (1), 99-120.

Barney, J. (1986). Strategic factor markets: Expectations, luck and business strategy. Management Science , 32 (10), 1231-1241.

Bartlett, C. A., \& Ghoshal, S. (1998). Beyond strategic planning to organization learning: lifeblood of the individualized corporation. Strategy \& Leadership , 26 (1), 34-9.

Bates, R., \& Khasawehn, S. (2005). Organizational learning culture, learning transfer climate and perceived innovation in Jordanian organizations. International Journal of Training and Development , 9 (2), 96-109.

Bates, R., \& Khasawneh, S. (2005). Organizational Learning Culture, Learning Transfer Climate and Perceived Innovation in Jordanian Organizations. International Journal of Training and Development , 9 (2), 96-109.

BBC News. (2015, Nov. 18). United Arab Emirates country profile. Retrieved Sep. 7, 2016, from bbc: http://www.bbc.com/news/world-middle-east-14703998

Becker, B., \& Gerhart, B. (1996). The impact of human resource management on organizational performance: progress and prospects. The Academy of Management Journal , 39 (4), 779-801.

Becker, B., \& Huselid, M. (1998). High performance work systems and firm performance:a synthesis of research and managerial implications. Research in Personnel and HRM , 16, 53-101.

Bharadwaj, A. S. (2000). A resource-based perspective on information technology capability and firm performance: an empirical investigation. MIS Quarterly , 24 (1), 169-196.

Bontis, N., Crossan, M., \& Huallnd, J. (2002). Managing an organizational learning system by aligning stocks and flows. Journal of Management Studies , 39A, 437-469.

Bontis, N., Dragonetti, N. C., Jacobsen, K., \& Roos, G. (1999). The knowledge toolbox: Areview of the tools available to measure the manage intangible resources. European Management Journal , 17 (4), 391-402.

Boxall, P., \& Purcell, J. (2000). Strategic human resource management: where have we come from and where should we be going? International Journal of Management Reviews , 2 (2), 183-203.

Breda-Verduijn, H. v., \& Heijboer, M. (2016). Learning culture, continuous learning, organizational learning anthropologist. Industrial and Commercial Training , 48, 123-128.

Breda-Verduijn, H. v., \& Heijboer, M. (2016). Learning culture, continuous learning, organizational learning anthropologist. Industrial and Commercial Training , 48 (3), 123 - 128.

Brown, M. a. (2003). Learning organizations in the public sector?Astudy of police agencies employing information and technology to advance knowledge. Public Administration Review , 63 (1), 30-43.

Carter, S., \& Greer, C. (2013). Strategic leadership: values, styles, and organizational performance. Journal of Leadership \& Organizational Studies , 20 (4), 375-393.

Cerimagic, S. (2010). Insights from Australian project managers in UAE. Education, Business and Society: Contemporary Middle Eastern Issues , 3 (4), 277-288.

Chen, C. J., \& Huang, J. W. (2009). Strategic human resource practices and innovation performance - The mediating role of knowledge management capacity. Journal of Business Research, 62 (1), 104-114.

Chen, C., \& Huang, J. (2009). Strategic human resource practices and innovative performance: the mediating role of knowledge management capacity. Journal of Business Research , 62 (1), 104-114.

2523-6547 - Copyright: (C) 2017 The Authors. This is an open access article distributed under the terms of the Creative Commons Attribution License, which permits unrestricted use, distribution, and reproduction in any medium, provided the original author and source are credited. 
Chew, I. K., \& Sharma, B. (2005). The effects of culture and HRM practices on firm performance: Empirical evidence from Singapore. International Journal of Manpower, 26 (6), 560-581.

Chiva, R., \& Alegre, J. (2009). Organizational learning capability and job satisfaction: an empirical assessment in the ceramic tile industry. British Journal of Management , 20 (3), 323-340.

Chiva, R., Alegre, J., \& Lapiedra, R. (2007). Measuring organisational learning capability among the workforce. International Journal of Manpower , 28 (3/4), 224-242.

Collins, C., \& Smith, K. (2006). Knowledge exchange and combination: the role of human resource practices in the performance of high-technology firm. Academy of Management Journal , 49 (3), 544-560.

Conner, M. L., \& Clawson, J. G. (2004). Creating a learning culture: Strategy, technology, and practice. Canbridge, UK: Cambridge University Press.

Cornwell, A. (2013, OCT. 3). Conference in Dubai highlights recruitment challenges. Retrieved Sep. 3, 2016 , from GulfNews Employment: http://gulfnews.com/business/sectors/employment/conference-in-dubaihighlights-recruitment-challenges-1.1239022

Crossan, M. M., Lane, H. W., \& White, R. E. (1999). An organizational learning framework: From intuition to institution. Academy of Management Review , 24 (3), 522-537.

Damanpour. (1991). Organizational innovation: a meta-analysis of effects of determinants and moderators. Academy of Management Journal , 34 (3), 555-590.

Delery, J. E., \& Doty, D. H. (1996). Modes of theorizing in strategic human resource management: Tests of universalistic, contingency, and configurational performance predictions. Academy of Management Journal , 39 (4), 802-835.

Delery, J. E., \& Doty, D. H. (1996). Modes of theorizing in strategic human resource management: tests of universalistic, contingency, and configurational perspectives. Academy of Management Journal , 39, 802-805.

Delery, J. (1998). Issues of fit in strategic Human resource management: Implications for research. Human Resource Management Review , 8, 289-310.

Delery, J., \& Shaw, J. (2001). The strategic management of people in work organizations: review, synthesis and extension. Greenwich: JAI Press.

Department of Statistics and Community Development. (2014, Dec 13). Statistical Year Book - 2014. Retrieved Sep 19, 2016, from department of statistics and community development sharjah: http://www.dscd.ae/Attachments/2014\%20year\%20book.pdf

Diaz-Fernandez, M., Bornay-Barrachina, M., \& Lopez-Cabrales, A. (2015). Innovation and firm performance: the role of human resource management practices. Evidence-based HRM: a Global Forum for Empirical Scholarship , 3 (1), 64 - 80.

Dimovski, V. (1994). Organizational learning and competitive advantage.PhD thesis.

Dougherty, D. (1996). Organizing for innovation. Sage, London: Handbook of Organization Studies.

Egan, T., Yang, B., \& Bartlett, K. (2004). The effects of organizational learning culture and job satisfaction on motivation to transfer learning and turnover intention. Human Resource Development Quarterly , 15 (3), 279 301.

2523-6547 - Copyright: (C) 2017 The Authors. This is an open access article distributed under the terms of the Creative Commons Attribution License, which permits unrestricted use, distribution, and reproduction in any medium, provided the original author and source are credited. 
Ekvall, G., \& Ryhammar, L. (1999). The Creative Climate: Its Determinants and Effects at a Swedish University. Creativity Research Journal , 12 (4).

Ellinger, A., Ellinger, A., Yang, B., \& Howton, S. (2002). The relationship between the learning organization concept and firm's financial performance: an empirical assessment. Human Resource Development Quarterly, $13(1), 5-21$.

Farouk, S., Elanain, H. M., Obeidat, S. M., \& Al-Nahyan, M. (2016). HRM practices and organizational performance in the UAE banking sector: The mediating role of organizational innovation. International Journal of Productivity and Performance Management , 65 (6), 773-791.

Fiol, C., \& Lyles, M. (1985). Organizational learning. Acad Manage Rev 1985 , 10 (4), 803-813.

Fong, C.-Y., Ooi, K.-B., Tan, B.-I., Lee, V.-H., \& Chong, A. Y.-L. (2011). HRM practices and knowledge sharing: an empirical study. international Journal of Manpower, 32 (5/6), 704-723.

Franklin Covey ME. (2016, April 14). What is the biggest challenge facing business leaders? Retrieved Aug 15, 2016, from changeboard: http://www.changeboard.ae/content/5526/what-is-the-biggest-challenge-facingbusiness-leaders/

Frost, A. (2010). Organizational Learning Theory from a Company-Wide Perspective. Retrieved Nov 20, 2016, from An Educational KM site: http://www.knowledge-management-tools.net/organizational-learningtheory.html

Gagliardi, P. (1986). The creation and change of organizational cultures: a conceptual framework. Organizational Studies , 7 (2), 117-134.

García-Moralesa, V. J., Lloréns-Montesa, F. J., \& Verdú-Joverb, A. J. (2007). Influence of personal mastery on organizational performance through organizational learning and innovation in large firms and SMEs.

Technovation , 27 (9), 547-568.

Garvin, D. A. (1993). Building a learning organization. Harvard Business Review , 71, 78-91.

Garvin, D. (1985, July-August). Building a learning organization. Harvard Business Review , pp. 78-91.

Goh, S. C., Elliott, C., \& Quon, T. K. (2012). The relationship between learning capability and organizational performance: A meta-analytic examination. The Learning Organization , 19 (2), 108.

Grant, R. M. (2005). Toward a knowledge-based theory of the firm. Strategic Management Journal , 8 (2), 147164.

Grant, R. (1996). Prospering in dynamically-competitive environments: organizational capability as knowledge integration. Organization Science , 7 (4), 375-387.

Griffith, D. (2006). Human capital in the supply chain of global firms. Organizational Dynamics , 35 (3), 251 263.

Gupta, A., \& Singhal, A. (1993). Managing human resources for innovation and creativity. Research Technology Management, 36 (3), 8-41.

Habboush, M. (2013, Oct. 10). Call to naturalise some expats stirs anxiety in the UAE. Retrieved Sep. 3, 2016, from Reuters: http://uk.reuters.com/article/uk-emirates-citizenship-feature-idUKBRE99904J20131010

Hedberg, B. (1981). How Organizations Learn and Unlearn (Vol. Handbook of Organizational Design). P.C. Nystrom \& W. H. Starbuck, London: Cambridge University Press.

2523-6547 - Copyright: (C) 2017 The Authors. This is an open access article distributed under the terms of the Creative Commons Attribution License, which permits unrestricted use, distribution, and reproduction in any medium, provided the original author and source are credited. 
Henderson, B. (2015, Feb 26). Organizational Learning \& Innovation. Retrieved Nov 17, 2016, from linkedin: https://www.linkedin.com/pulse/organizational-learning-innovation-brian-henderson

Hiltrop, J. M. (1996). Managing the changing psychological contract. Employee Relations , 18 (1), 36-49.

Holton, E. I. (2000). Relationship between learning organization strategies and performance driver outcomes. Baton Rouge, LA: Academy of Human Resource Development Conference Proceedings, Academy of Human Resource Development.

Hooi, L. W., \& Ngui, K. S. (2014). Enhancing organizational performance of Malaysian SMEs: the role of HRM and organizational learning capability. International Journal of Manpower , 35 (7), 973-995.

Huber, G. P. (1991). Organizational learning: The contributing process and the literatures. Organization Science , 2 (1), 88-115.

Hult, G., Hurley, R., \& Knight, G. (2004). Innovativeness: Its antecedents and impact on business performance. Industrial Marketing Management, 33, 429-438.

Hurley, R., \& Hult, G. (1998). Innovation, market orientation and organizational learning: An integration and empirical examination. The Journal of Marketing , 62, 42-54.

Huselid, M. A., Jackson, S. E., \& Schuler, R. S. (1997). Technical and Strategic Human Resources Management Effectiveness as Determinants of Firm Performance. Academy of Management Journal , 40, $171-88$.

Huselid, M. (1995). The impact of human resource management on turnover, productivity, and corporate financial performance. Academy of Management Journal , 38 (3), 635-672.

Hussein, N., Omar, S., Noordin, F., \& Ishak, N. A. (2016). Learning Organization Culture, Organizational Performance and Organizational Innovativeness in a Public Institution of Higher Education in Malaysia: A Preliminary Study. Procedia Economics and Finance , 37, 512-519.

Ismail, M. (2005). Creative climate and learning orgnization factors: their contribution towards innovation. Leadership \& Organization Development Journal , 26 (8), 639-654.

Jacobs, K. (1998). Costing health care: a study of the introduction of cost and budget reports into a GP association. Management Accounting Research , 9 (1), 55-70.

Jandeska, K., \& Kraimer, M. (2005). Women's perceptions of organizational culture, work attitudes, and rolemodeling behaviors. Journal of Management Issues , 17, 461-478.

Jerez-Gomez, P., Cespedes-Lorente, J., \& Valle-Cabrera, R. (2005). Organizational learning capability: a proposal of measurement. Journal of Business Research , 58 (6), 715-725.

Jiménez-Jiménez, D., \& Sanz-Valle, R. (2011). Innovation, Organizational Learning, and Performance. Journal of Business Research , 64, 408-417.

Juani S. \& Nicholas K. (2010). Organisational learning, knowledge assets and HR practices in professional service firms. Human Resource Management Journal , 20 (1), 64-79.

Kalmuk, G., \& Acar, A. (2015). The Mediating Role of Organizational Learning Capability on the Relationship Between Innovation and Firm's Performance: A Conceptual Framework. Procedia - Social and Behavioral Sciences , 210, 164-169.

Kandekar, A., \& Sharma, A. (2006). Organizational learning and performance: Understanding Indian scenario in present global context. Education and Training , 48 (9), 682-692.

2523-6547 - Copyright: (C) 2017 The Authors. This is an open access article distributed under the terms of the Creative Commons Attribution License, which permits unrestricted use, distribution, and reproduction in any medium, provided the original author and source are credited. 
Kang, S.-C., Morris, S. S., \& Snell, S. A. (2007). RELATIONAL ARCHETYPES, ORGANIZATIONAL LEARNING, AND VALUE CREATION: EXTENDING THE HUMAN RESOURCE ARCHITECTURE. Academy of Management Review , 32 (1), 236-256.

Kanter, R. M. (1984). Innovation--the only hope for times ahead? Sloan Management Review , 25 (4), 51-55.

Katou, A. A. (2008). Measuring the impact of HRM on organizational performance. Journal of Industrial Engineering and Management, 1 (2).

Khilji, S. E. (2001). Human Resource Management in Pakistan. Human Resource Management in Developing Countries , 102-120.

Kieser, A., \& Koch, I. (2008). Bounded rationality and organizational learning based on rule changes. Management Learning , 39 (3), 329-347.

Kim, D. H. (1998). The Link between Individual and Organizational Learning. Sloan Management Review , $37-$ 50 .

Kogut , B., \& Zander, U. (1992). Knowledge of the Firm, Combinative Capabilities, and the Replication of Technology. Organization Science , 3 (3), 383-397.

Kontoghiorghes, C., Awbre, S., \& Feurig, P. (2005). Examining the relationship between learning organization characteristics and change adaptation, innovation, and organizational performance. Human Resource Development Quarterly, 16 (2), 185-212.

Koskinena, K. U., Pihlantob, P., \& Vanharantaa, H. (2003). Tacit knowledge acquisition and sharing in a project work context. International Journal of Project Management , 21 (4), 281-290.

Lei, d., slocum, j. w., \& pitts, r. a. (1999). Designing organizations for competitive advantage: the power of unlearning and learning. Organizational Dynamics , 27 (3), 24-38.

Lengnick-Hall, M. L., Lengnick-Hall, C. A., \& Rigsbee, C. M. (2013). Human resource management and supply chain orientation. Human Resource Management Review , 23 (4), 366-377.

Lepak, D., \& Snell, S. (1999). The human resource architecture: toward a theory of human capital allocation and development. Academy of Management Journal , 13, 31-48.

Liao, S.-h., Fei, W.-C., \& Liu, C.-T. (2008). Relationships between knowledge inertia, organizational learning and organization innovation. Technovation , 28, 183-195.

Libo-on, L. (2013, Jun 1). About Sharjah: Around the city in 1.15h. Retrieved Nov 10, 2016, from McClatchy Tribune Business News: http://search.proquest.com/docview/1357182049?accountid=44597

Limpibunterng, T., \& Johri, L. M. (2009). Complementary role of organizational learning capability in new service development (NSD) process. The Learning Organization , 16 (4), 326 - 348.

Lin, H.-F. (2007). Knowledge sharing and firm innovation capability: an empirical study. International Journal of Manpower , 28 (3/4), 315-332.

López, S. P., Peón, J. M., \& Ordás, C. J. (2005). Organizational learning as a determining factor in business performance. The Learning Organization , 12 (3), 227-45.

MacDuffie, J. (1995). Human resource bundles and manufacturing performance: organizational logic and flexible production system in the world auto industry. Industrial and Labor Relations Review , 48 (2), $197-221$.

2523-6547 - Copyright: (C) 2017 The Authors. This is an open access article distributed under the terms of the Creative Commons Attribution License, which permits unrestricted use, distribution, and reproduction in any medium, provided the original author and source are credited. 
Malit.Jr., F. T., \& Youha, A. A. (2013, Sep. 18). Labor Migration in the United Arab Emirates: Challenges and Responses. Retrieved Sep. 3, 2016, from Migration Policy Institute:

http://www.migrationpolicy.org/article/labor-migration-united-arab-emirates-challenges-and-responses

Marquardt, M. J. (1996). Building the Learning Organization: A Systems Approach to Quantum Improvement and Global Success. New York: McGraw-Hill.

Miller, D. (1996). A preliminary typology of organisational learning: Synthesizing the literature. Journal of Management, 22 (3), 485-505.

Moideenkutty, U., Al-Lamki, A., \& Murthy, Y. S. (2011). HRM practices and organizational performance in Oman. Personnel Review , 40 (2), 239-251.

Moorsel, M. B.-V. (2003). Leerklimaat: de culturele dimensie van leren in organisaties. Delft: academic dissertation.

Murray, P., \& Donegan, K. (2003). Empirical linkages between firm competencies and organisational learning. The Learning Organization , 10 (1), 51-62.

Nawab, S., Shafi, K., \& Ahmad, J. (2010). Organizational culture as determinant of employee commitment: evidence from Pakistan. Interdisciplinary Journal of Contemporary Research in Business , 2, 259-268.

Njau, B. (2013). Supplement: Sharjah - sectors - shining across sectors. Retrieved Nov 8, 2016, from Foreign Direct Investment: http://search.proquest.com/docview/1335070922?accountid=44597

Nonaka, I., Toyama, R., \& Hirata, T. (2008). Managing Flow: A Process Theory of the Knowledge-based Firm. NY: Palgrave Macmillan.

OECD. (1997). OECD propdrf Guidelines for collecting and interpreting technological innovation data. Paris: OECD/GD.

Paauwe, J. a. (2005). HRM and performance, what next? Human Resource Management Journal, 15 (4), 68-83.

Paauwe, J., \& Boselie, P. (2005). HRM and performance: What's next? Human Resource Management Journal, $15(4), 68-83$.

Pokharel, M. P., \& Choi, S. O. (2015). Exploring the relationships between the learning organization and organizational performance. Management Research Review , 38 (2), 126-148.

Power, J., \& Waddell, D. (2004). The link between self-managed work teams and learning organizations using performance indicators. The Learning Organization, 11 (3), 244-259.

Prieto, I. M., \& Pérez-Santana, M. P. (2014). Managing innovative work behavior: the role of human resource practices. Personnel Review , 43 (2), 184-208.

Ronald E Purser, W. A. (1992). Organizing for learning. Research in organizational change and development, $6(3), 37-114$.

Ruona, W., \& Gibson, S. (2004). The making of twenty-first-century HR: an analysis of the convergence of HRM, HRD, and OD. Human Resource Management , 43 (1), 49-66.

Rutherford, M., Buller, P., \& McMullen, P. (2004). Human resource management problems over the life cycle of small to medium-sized family firms. Human Resource Management, 42 (4), 321-336.

2523-6547 - Copyright: (C) 2017 The Authors. This is an open access article distributed under the terms of the Creative Commons Attribution License, which permits unrestricted use, distribution, and reproduction in any medium, provided the original author and source are credited. 
Salancik, G. R., \& Meindl, J. R. (1984). Corporate attributions as strategic illusions of management control. Administrative Science Quarterly, 29 (2), 238-254.

Scarbrough, H. (2003). Knowledge management, HRM and the innovation process. International Journal of Manpower, 24 (5), 501-516.

Schein, E. H. (1997). Organizational Culture and Leadership (2nd ed ed.). San Francisco, CA: Jossey-Bass.

Senge, P. (1990). The fifth discipline: the art \& practice of the learning organization. London: Ramdom House.

Senge, P. (1990). The Fifth Discipline: The Art and Practice of the Learning Organization. New York, NY.: Currency Doubleday.

Sengupta, S., \& Sinha, J. (2005). Perceived dimensions of societal and organizational cultures and their impact on managerial work behavior. Journal of Management Research, , 5, 143-172.

Shalley, C. E., Zhou, J., \& Oldham, G. R. (2004). The Effects of Personal and Contextual Characteristics on Creativity: Where Should We Go from Here? Journal of Management, 30 (6), 933-958.

Sharjah update newsletter . (2015, Feb 26). Sharjah ups public sector wages. Retrieved Nov 14, 2016, from Sharjah Update: http://www.sharjahupdate.com/2015/02/sharjah-ups-public-sector-wages-2/

Sheehan, M., Garavan, T. N., \& Carbery, R. (2014). Innovation and human resource development (HRD). European Journal of Training and Development , 38 (1/2), 2-14.

Shih, H., Chiang, Y., \& Hsu, C. (2006). Can high performance work systems really lead to better performance? International Journal of Manpower, 27 (8), 741-776.

Simonin, B. L. (1997). The Importance of Collaborative Know-How: An Empirical Test of the Learning Organization. The Academy of Management Journal , 40 (5), 1150-1174.

Singh, N. R., \& Kassa, B. (2016). The Impact of Human Resource Management Practice on Organizational Performance - A Study on Debre Brehan University. International Journal of Recent Advances in Organizational Behaviour and Decision Sciences , 1 (1).

Slater, S. F., \& Narver, J. C. (1995). Market Orientation and Learning Organization. Journal of Marketing , 59 (3), 63-74.

Sluis, L. E. (2004). Designing the workplace for learning and innovation : Organizational factors affecting learning and innovation. Development and Learning in Organizations: An International Journal , 18 (5), 10-13.

Smith, G. (2013). What challenges are employees facing in the Middle East? Changeboard magazine .

Sorakraikitikul, M., \& Siengthai, S. (2014). Organizational learning culture and workplace spirituality Is knowledge-sharing behaviour a missing link? The Learning Organization, 21 (3), 175-192.

Stainer, A. (1999). Productivity, performance and paradise. Management Services , 43 (6), 8-11.

Stankard, M. (2002). Management systems and organizational performance: The search for excellence beyond ISO9000. Westport, CT: Greenwood Publishing Group.

Starbuck, W. H. (1983). Organizations as Action Generators. American Sociological Review , 48 (1), 91-102.

Stata, R. (1989). Organizational Learning The Key to Management Innovation. Sloan Management Review , 30 (3), 63-74.

2523-6547 - Copyright: (C) 2017 The Authors. This is an open access article distributed under the terms of the Creative Commons Attribution License, which permits unrestricted use, distribution, and reproduction in any medium, provided the original author and source are credited. 
Takeuchi, H., \& Nonaka, I. (1995). The Knowledge Creating Company: How Japanese Companies Create the Dynamics of Innovation. New York, NY: Oxford University Press.

Tan, C. L., \& Nasurdin, A. M. (2011). Human Resource Management Practices and Organizational Innovation: Assessing the Mediating Role of Knowledge Management Effectiveness. The Electronic Journal of Knowledge Management, 9 (2), 155-167.

Teece, D. J., Pisano, G., \& Shuen, A. (1997). Dynamic capabilities and strategic management. Strategic Management Journal , 18 (7), 509-533.

Tran, T. (2008). A conceptual model of learning culture and innovation schema. Competitivness Review: An International Business Journal , 18 (3), 287-299.

Ussahawanitchakit, P. (2008). Impacts of organization learning on innovation oreintation and firm efficiency: An empirical Asessment of Accounting Firms in Thailand. International Journal of Business Research, 8 (4), $1-12$.

Vijayakumar, V., \& Padma, R. (2014). Impact of perceived organizational culture and learning on organizational identification. International Journal of Commerce and Management , 24 (1), 40-62.

Wang, X. (2007). Learning, job satisfaction and commitment: an empirical study of organizations in China. Chinese Management Studies, , 1 (3), 167-179.

Wang, Y.-L., \& Ellinger, A. D. (2011). Organizational learning Perception of external environment and innovation performance. International Journal of Manpower , 32 (5/6), 512-536.

Wang, Z. M. (2005). Organizational effectiveness through technology innovation and HRM strategies. International Journal of Manpower, 26 (6), 481-487.

Wang, Z. (2005). Organizational effectiveness through technology innovation and HRM strategies. International Journal of Manpower, 26 (6), 481-487.

Watkins, K. E., \& Marsick, V. J. (1999). Facilitating learning organizations: Making learning count. Aldershot: Gower Publishing Limited.

Watkins, K. E., \& Marsick, V. J. (1993). Sculpting the Learning Organization Lessons in the Art and Science of Systematic Change. San Francisco, CA.: Jossey-Bass.

Watkins, K., \& Marsick, V. (1996). In Action: Creating the Learning Organization. Alexandria, VA: American Society for Training and Development.

Watkins, K., \& Marsick, V. (1996). In Action: Creating the Learning Organization. Alexandria, VA.: American Society for Training and Development.

Wei, L.-Q., Wu, L.-Z., Cheung, Y., \& Chiu, R. K. (Winter 2011/2012). Knowledge resources, learning orientation and firm performance. Journal of General Management , 37 (2), 69-88.

Weldy, T. (2009). Learning organization and transfer: strategies for improving performance. The Learning Organization , 16 (1), 58-68.

Wikipedia. (n.d.). Emirate of Sharjah. Retrieved Sep 19, 2016, from Wikipedia: https://en.wikipedia.org/wiki/Emirate_of_Sharjah

Wong, K. (2005). Critical success factors for implementing knowledge management in small and medium enterprises. Industrial Management \& Data Systems , 105 (3), 261-279.

2523-6547 - Copyright: (C) 2017 The Authors. This is an open access article distributed under the terms of the Creative Commons Attribution License, which permits unrestricted use, distribution, and reproduction in any medium, provided the original author and source are credited. 
Wright, P., \& McMahon, G. (1992). Theoretical perspective for strategic human resource management. Journal of Management , 18 (2), 295-320.

Yang, J.-t. (2007). The impact of knowledge sharing on organizational learning and effectiveness. Journal of Knowledge Management, 11 (2), 83-90.

Yeo, R. (2005). Revisiting the roots of learning organization: a synthesis of the learning organization literature. The Learning Organization, 12 (4), 368-382.

Yolles, M. (2009). Competitive advantage and its conceptual development. Business Information Review , 26 (2), 93-111.

Youndt, M. A., Snell, S. A., Dean, J. W., \& Lepak, D. P. (1996). Human resource management, manufacturing strategy and firm performance. Academy of Management Journal , 39 (4), 836-866.

Yousif, M. (2015). Managers and Team Leaders vs The Fear of the Self-produce Culture. Training Magazine Middle East .

Zhai, X., Liu, A. M., \& Fellows, R. (2014). Role of Human Resource Practices in Enhancing Organizational Learning in Chinese Construction Organizations. Journal of Management in Engineering , 30 (2), 194-204.

Zhao, Z. Y., \& Shen, L. Y. (2008). Are Chinese contractors competitive in international markets? Construction Management and Economics , 26 (3), 225-236.

Zott, C. (2003). Dynamic Capabilities and the Emergence of Intraindustry Differential Firm Performance: Insights From a Simulation Study. Strategic Management Journal , 24 (2), 97-125. 
2523-6547 - Copyright: (C) 2017 The Authors. This is an open access article distributed under the terms of the Creative Commons Attribution License, which permits unrestricted use, distribution, and reproduction in any medium, provided the original author and source are credited. 